\title{
AZ INNOVÁCIÓ NEM HARCI JELSZÓ, HANEM FOLYAMAT
}

\section{INNOVATION: NOT A WARRIOR'S SLOGAN BUT A PROCESS}

\author{
Vámos Tibor \\ az MTA rendes tagja, professor emeritus \\ vamos@sztaki.mta.hu
}

Innováció, korunk egyik legdivatosabb jelszava, amely fedheti a rák pillanatok alatt történő felismerését és gyógyítását, az ivóvíz párából történő előállítását, de a szoknyák kézi szabásáról a gépi szabására történő áttérést is. A modern fizika eredményeiből építkezik többek között az egész félvezető technológia. Ha ilyen tág a fogalom, valószínüsíthető, hogy legalább ilyen tág az eszközök, eljárások, szokások birodalma is. A technikával és a társadalommal foglalkozó ember még a rákhasonlatnál is szélesebb értelmezésben használja, számára az innováció egy adott társadalom életviszonyainak jobbítása. Ha pedig ebben az értelmezésben emelünk szót, akkor az innovációval igyekszünk megmozdítani mindazt a társadalmat meghatározó, befolyásoló eszközt és körülményt, ami ezzel az emeléssel járhat.

\section{NAGY INNOVÁCIÓK ÉS NAGY INNOVÁTOROK}

Emlékezetünkből elősorolódnak a jellegzetes példák: a kerék, az ekével való szántás, a könyvnyomtatás, gőzvontatás, repülés, mikroszkópia és bakteriológia, nukleáris technika, csere a pénz segítségével, kapitalizmus. Mindez a mögöttük alakult gondolkodásmódokkal, az egyistenhitekkel, az emberi jogokkal, a szocializmussal és a csoportalakulások érzelmi világaival.

Az ilyen egyszerüsítő jelzőkőként is használt megnevezéseket példázzák szép, tizenkilencedik századi középületeink díszítésében magasodó férfialakok, szójárásunkban a Nagy Innovátorok.

Mostani képletünk, amely egyben segítő kísérlet az elöbbre vivőnek tekinthető folyamatok megítélésében és felmérésében, összetettebb. Ez az összetettség ugyan végigvonul a történet egészén, de különös hangsúlyt kap a ma bonyolultságában. Ezért igyekszünk először ebben a bozótban példákkal is ösvényeket vágni. 


\section{TÖRTÉNELMI PÉLDACSODÁK}

A történelem kutatói számára is kérdéses, hogy az antikvitás technikai kultúrája miért nem fejlődött tovább olyan szerves módon, mint ahogy azt óriási kihagyás után a tizennyolcadik század ipari forradalma gerjesztette. Az egyik, erős magyarázat a rabszolgamunka adott lehetősége, ennek bővíthetősége hódításokkal. Valamilyen hasonlósággal ez ismétlődött meg az amerikai Észak és Dél viszonyaiban, ekkor már a közben eltelt kétezer év eszközbeli és gondolkodási hátterével.

Csodáljuk azokat a viszonylag rövid időszakokat, amelyekben a müvészetek különösen koncentrált gazdagsága jött létre, az észak-itáliai reneszánszt, a késő gótika flamand és a korai kapitalizmus németalföldi festészetét, a zene tizenhetediktől a huszadikig teremtő németföldi virágzását vagy a tizenkilencedik század hirtelen elöretörő orosz irodalmát.

Mindegyik szerteágazó és gazdag tárgyi és szellemi előélet nyomán és talaján alakult, mint ahogy a matematika és a természettudományok ideálképként megjelent, tizenhetedik századot követő robbanása, a Newtonok, Eulerek, Gaussok Európája.

Ma már hatalmas irodalma van a relativitáselmélet és a kvatumfizika szellemi mozgástörténetének, többek között a tizenkilencedik század matematikai elméleti eredményei eredetileg váratlan szerepeinek.

A feltételrendszerek sajátos bonyolultságát mutatja a jelenkor majdnem valamennyi nagy eredményének története. Így a holográfia az interferenciák érdekes jelensége volt a lézertechnikáig, az aviatika évezredes szép álom a fizika, a kémia és az anyagtudományok nehezen megszámlálható változatosságú és kölcsönhatású haladásával a repülés mindennapjáig. A példák a megszámlálhatósági határokig sorolhatók.

\section{INNOVÁCIÓS ORSZÁGSIKEREK}

Hasonló eredettörténetek szólnak egyes országok és régiók meglepő feltöréseiről. Az észak-európai, ezen belül is a finn csoda gyökereit többek között abban a száz évnél is sokkal régebbi állapotban lelhetjük fel, amit az írástudás elterjedtsége mutat: a tizenkilencedik és huszadik század fordulóján ez a magyar népesség körülbelül feléig ért el, ugyanakkor a finnek már majdnem teljes lakossága írástudó volt.

A Távol-Kelet technológiai és életviszonyokbeli előreugrását több mint kétezer év folyamatos munka- és szervezetkultúrája alapozta meg, ami nagymértékben az öntözés és az ehhez kapcsolódó mezőgazdaság gazdálkodásából táplálkozott, szemben a kelet-európai nagy- és kisbirtokok gazdasági szigetvilágaival, amit csak a kereskedelem általában ellenségesnek tekintett elöretörése bontott meg, sokszor iszonyú áldozatok, kataklizmák árán. 
A szemlélő számára mindez a majdnem triviális ismerettömeg különös ellentmondásban jelenik meg azokban a voluntarista törekvésekben, amelyek a modernizáció vonzásában fejveszett módon igyekeznek előretörni. Ilyenek voltak már a felvilágosodott abszolutizmusok csődjei, a huszadik század borzalmai, a fasizmusok és a szovjet rémuralmai. Kevésbé szörnyüségesen vallottak kudarcot a többi, centrális akaratokat hajszoló törekvések. Velük szemben kínlódtak a konzervatív rendszerek szűk látókörü, nosztalgiákra építő visszafogási politikái.

\section{NEMZETI PÉLDÁNK: A JÓZAN ÚT}

Van-e célravezetőbb, józanabb út e szélsőségek Szküllái és Kharübdiszei között? Van kitűnő nemzeti példánk, a tizenkilencedik század magyarországi szabadgondolkodó reformpolitikája. Hangsúlyozom a teljes századot, mert a közepének nagy és tragikus törései ellenére ez az alaptörekvés majdnem változatlan maradt a rendi világ és a polgári demokrácia felé haladás időszakában: megteremteni az innováció már akkor is bonyolult hálójának infrastrukturális alapjait. Ezek voltak a közoktatás valamennyi szinten, a kultúra különböző független szerkezetei, a mobilitáshoz elengedhetetlen közlekedésfejlesztés és azoknak a csoportoknak a tudatosan szabadságokat szélesítő befogadása és integrálása, amelyek az innovációt importálják. Erős központosító és állami támogatású törekvés csak a közlekedésfejlesztésben és az azt megvalósító iparban érvényesült.

Ennek a liberális, százados fejlődést megelőlegező politikának persze rengeteg ellenzője is volt, többek között azok a földbirtokos érdekek és nacionalista elzárkózások, amelyek a korszak tragikus végét siettették, de mégis, ez eredményezte azt a máig is csodálható innovációs ugrást, amely a magyar történelemben a legközelebb vitte az országot és népét az európai fejlődéshez.

Az innováció nem egyéni elképzelések és kényszeres akciók eredménye, hanem kultúra, a szó szorosabb és a természethez közelítőbb értelmében: talajmüvelés, magvak szórása és ígéretes palánták gondozó támogatása, a természet elengedhetetlen bőkezüségének és várakozásainak bölcs türelme.

Ezt a bölcsességet igyekszik magának megtakarítani a mostani keserủ voluntarizmus, az a sarlatánság, ami vajákos módon, kitapogatás, hallgatás és képi betekintés nélkül operál müködő testrészeket. A bün halálos! 